\title{
International Cooperation and the Protection of Persons Affected by Sea-Level Rise
}

\author{
Drawing the Contours of the Duties of Non-affected States
}

Patrícia Galvão Teles, ${ }^{*}$ Claire Duval ${ }^{* *}$ and Victor Tozetto da Veiga ${ }^{* * *}$

In recent years, the prospect of rising sea-levels as an adverse impact of climate change has gained increasing importance for a significant part of the international community. More than 70 States are likely to see their territories partially or completely inundated as a result of this slow-onset phenomenon, which jeopardises the habitability of often densely populated areas and puts a large number of persons' lives and livelihoods at risk. ${ }^{1}$ Without timely and proactive interventions, moreover, displacement to other States is likely to become inevitable. In light of the global impact of sea-level rise, international cooperation is vital to adequately respond to it, mitigate its damaging effects, and protect those affected by it. Cooperation is therefore a practical necessity and a moral imperative.

Cooperation is, in addition, a legal duty imposed by international law. In 2016, the International Law Commission (ILC) sought to give precise legal content to the principle and duty to cooperate in disaster relief in the context of the adoption of the Draft Articles on the Protection of Persons in the event of Disasters (the Draft Articles). ${ }^{2}$ The objective was, in part, to find a balance between the rights and obligations of affected States and those of non-affected States and other relevant actors. According to the Draft Articles, affected States

\footnotetext{
* Associate Professor of International Law at the Autonomous University of Lisbon, Portugal. Member of the United Nations International Law Commission and Co-Chair of the Study Group on "Sea-level rise in relation to international law". E-mail address: pgalvaoteles@gmail.com. This contribution is written in a personal capacity.

** LL.M. Candidate at Stanford Law School, International Economic Law, Business and Policy, Stanford, USA.

*** Master's student in International Law at the Graduate Institute of International and Development Studies, Geneva, Switzerland.

1 ILC, 'Report of the International Law Commission', seventieth session (30 April1 June and 2 July-10 August 2018) UN Doc A/73/10, Annex B, para. 1.

2 ILC, 'Report of the International Law Commission', sixty-eighth session (2 May10 June and 4 July-12 August 2016), UN Doc A/71/10, paras. 48-49.
} 
have a legal obligation to seek assistance to the extent that a disaster manifestly exceeds their national response capacity, yet no corresponding legal obligation was allocated to non-affected States. As the only countervailing obligation imposed upon non-affected States is a passive one - that of expeditiously giving due consideration to requests for assistance -, the end-result is arguably asymmetrical to the detriment of affected States and might, under certain circumstances, impair the protection of affected persons. ${ }^{3}$

The ILC has recently included in its active agenda the topic 'Sea-level rise in relation to international law' and created a Study Group to examine the legal issues related to (i) Law of the Sea; (ii) Statehood; and (iii) Protection of Persons affected by sea-level rise. ${ }^{4}$ While the work of the Study Group is still at an early stage, ${ }^{5}$ addressing the legal framework for the protection of persons affected by sea-level rise provides a renewed opportunity to clarify the content and manifestations of non-affected States' duty to cooperate. Therefore, by exploring the duty of non-affected States to cooperate in relation to the protection of persons affected by sea-level rise, the objectives of this article are two-fold. It aims to contribute both to the efforts of addressing the threat posed by sea-level rise and to those of clarifying the contours of the duty to cooperate in international law.

Accordingly, this article will proceed in three parts. Section 2 looks at the threat posed by sea-level rise, which requires international cooperation to effectively protect those affected by it. Section 3 explores the duty to cooperate by examining its foundations in general international law and in two of the most relevant branches relating to the protection of persons affected by sea-level rise - namely international human rights law (IHRL) and international disaster law (IDL). Section 4 then draws the contours of the duty of non-affected States to cooperate in relation to the protection of persons affected by sea-level rise. It should be noted that cooperation by other actors, such as international organisations and other relevant key stakeholders, is not the object of the present contribution - although such cooperation is also of the utmost importance for the effective protection of persons affected by rising sea levels.

3 Flavia Zorzi Giustiniani, International Law in Disaster Scenarios: Applicable Rules and Principles (Springer 2021) 169-183.

4 ILC (n 1) and ILC, 'Report of the International Law Commission', seventy-first session (29 April-7 June and 8 July-9 August 2019), Chapter X.

5 For the most recent report, see ILC, 'Report of the International Law Commission', seventysecond session (26 April-4 June and 5 July-6 August 2021), UN Doc A/76/10, paras. 240-296. 
2

\section{Human Impacts of Sea-Level Rise and the Need for International Cooperation}

\section{Sea-Level Rise as a Consequence of Climate Change: 'One of the Greatest Challenges of Our Time'}

In 2015, all 193 Member States of the United Nations recognised climate change as one of the greatest challenges of our time. On this occasion, States stressed that the adverse impacts of climate change, including sea-level rise, are seriously affecting coastal areas and low-lying coastal countries and putting the survival of many societies and of the biological support systems of the planet at risk. ${ }^{6}$

The consideration of sea-level rise as one of the most significant effects of climate change is also evidenced by the findings of the Intergovernmental Panel on Climate Change ("IPCC"). In 2013, the IPCC estimated in its fifth Assessment Report that the global mean sea-level rise is likely to be between $26 \mathrm{~cm}$ and $98 \mathrm{~cm}$ by the year 2100. ${ }^{7}$ This is a considerable increase compared to the previous projections of up to $59 \mathrm{~cm} .{ }^{8}$ Recent scientific studies have suggested that the figures could be even higher, with some scenarios indicating that sea levels could rise as much as two meters by $2100 .{ }^{9}$ While estimates of sea-level rise differ significantly, the scientific evidence is clear on the fact that a significant increase in sea-level rise can be expected in the 21st century and that this phenomenon is likely to accelerate in the future.

\subsection{The Human Face of Sea-Level Rise}

Sea-level rise poses a significant threat to coastal and low-lying areas of the world. To name some physical impacts, rising sea levels expose coastal populations to losses of land due to an exacerbated risk of destructive erosion, inundation, and wetland flooding of low-lying coastal areas. Increased flooding will have particularly adverse consequences for the infrastructure, settlements, and agricultural lands located at or near the coasts. Higher sea

6 UNGA Res 70/1 (25 September 2015) UN Doc A/RES/70/1, para. 14.

7 IPCC, Climate Change 2013: The Physical Science Basis. Contribution of Working Group I to the Fifth Assessment Report of the Intergovernmental Panel on Climate Change (CUP 2013) $25^{-26 .}$

8 IPCC, Climate Change 2007: The Physical Science Basis. Contribution of Working Group I to the Fourth Assessment Report of the Intergovernmental Panel on Climate Change (CUP 2007) 13-14.

9 Martin Verneer, Stefan Rahmstorf, 'Global Sea Level Linked to Global Temperature' (Proceedings of the National Academy of Sciences of the USA, 2009) <http://www.pnas.org/ content/106/51/21527.full > last accessed (as any subsequent URL) on 14 March 2021. 
levels also promote saltwater intrusion into river estuaries and aquifers, causing stress to the supply of freshwater resources and reducing the bearing capacity of the ground. ${ }^{10}$ Studies of extreme sea levels worldwide have also indicated that sea-level rise brings with it more frequent and extreme events driven by severe weather such as tropical cyclones and mid-latitude storms, which further aggravate the physical changes aforementioned. ${ }^{11}$

Because sea-level rise is not a uniform phenomenon across time and space, ${ }^{12}$ the nature and intensity of these physical impacts will vary from region to region and locality to locality, ${ }^{13}$ depending, among other things, on terrain, climatic conditions, wealth, economic conditions, infrastructure and political institutions. ${ }^{14}$ Yet together, changes in sea-level rise and the frequency and intensity of extreme events have potentially significant socio-economic, environmental and cultural consequences for human lives and living conditions in coastal and low-lying areas. They threaten all aspects of human life, including livelihoods and industry, mortality, food and water security, health and wellbeing, homes, land and other property, infrastructure and critical services, and cultural heritage. ${ }^{15}$ Accordingly, although sea-level rise does not constitute in itself a violation of human rights, it has the potential to adversely affect the enjoyment of human rights, especially those of already vulnerable persons and groups. ${ }^{16}$

In resilient communities, the physical impacts of sea-level rise and associated extreme events which fall short of total submergence may be overcome through mitigation and adaptation strategies. ${ }^{17}$ However, in more severe cases

10 Nobuo Mimura, 'Sea-level rise caused by climate change and its implications for society' (2013) 89 Proceedings of the Japan Academy, Series B Physical and Biological Sciences, 291-295.

11 Antarctic Climate \& Ecosystems, 'Position analysis: climate change, sea-level rise and extreme events: impacts and adaptation issues' (NCMI Information and Data Center, 2008) 1-18.

12 Benjamin Horton et al, 'Mapping Sea-level Change in Time, Space and Probability' (2018) 43 Annual Review of Environment and Resources, 481-512.

13 Jane McAdam et al, 'International Law and Sea-Level Rise: Forced Migration and Human Rights' (2016), Fridtjof Nansen Institute, 2.

14 Sujatha Byravan, Sudhir Chella Rajan, 'The Ethical Implications of Sea-Level Rise Due to Climate Change' (2010) 24 Carnegie Council for Ethics in International Affairs, 240.

15 McAdam et al. (n 12) 4 .

16 Siobhan McInerney-Lankford, 'Chapter 8: Human Rights and Climate Change, Reflections on International Legal Issues and Potential Policy Relevance' in Michael Gerrard and Gregory Wannier (eds), Threatened Island Nations: Legal Implications of Rising Seas and a Changing Climate (CUP 2013) 195.

17 Anthony Oliver-Smith, 'Sea Level Rise and the Vulnerability of Coastal Peoples: Responding to the Local Challenges of Global Climate Change in the 21st Century' (2009) 7 InterSecTions, 28. 
where the habitability of coastal and low-lying areas is jeopardised and the adaptation and mitigation measures prove inadequate, these disruptions may leave residents of such areas with no choice but to relocate or migrate. Estimating the magnitude of this displacement or migration is challenging, because the impacts of sea-level rise interact with other economic, social and political factors which themselves force people from their homes. ${ }^{18}$ In the past ten years, $83 \%$ of all disasters triggered by natural hazards were caused by extreme weather and climate-related events. ${ }^{19}$ These events caused the displacement of 23.9 million people in 2019 alone.$^{20}$ Other studies estimate that there will be 146 million people at risk of having to evacuate their houses in the next century. ${ }^{21}$

Most involuntary displacement in this context will be internal as opposed to across international borders. However, without timely and proactive interventions, displacement to other States may become inevitable. ${ }^{22}$ In either scenario, sea-level rise has more potential to create long-term or definitive movement of people than any other form of environmentally induced human migration. ${ }^{23}$

\subsection{Sea-Level Rise and the Need for International Cooperation}

It is becoming increasingly clear that to cope effectively with the adverse impacts of sea-level rise, concerted international political action is required.

Sea-level rise poses a threat in almost all regions of the world. ${ }^{24}$ Projections suggest that sea levels in nearly $95 \%$ of the world's ocean area will rise by the end of the 21st century, leading $70 \%$ of the world's coastlines to experience

18 Gregory Wannier, Michael Gerrard, 'Chapter 1: Overview' in (eds) Threatened Island Nations: Legal Implications of Rising Seas and a Changing Climate (CUP 2013) 5.

19 IFRC, 'World Disaster Report 2020: Come Heat or High Water: Tackling the Humanitarian Impacts of the Climate Crisis Together' (2020) <https://media.ifrc.org/ifrc/wp-content/ uploads/2020/11/20201116_WorldDisasters_Full.pdf>.

20 IDMC, 'GRID 2020: Global Report on Internal Displacement' (2020) <https://www .internal-displacement.org/publications/2020-global-report-on-internal-displacement>.

21 Etienne Piguet, 'Research Paper No. 153: Climate change and forced migration' (UNHCR, 2008) <https:/www.unhcr.org/research/working/47a316182/climate-change-forced -migration-etienne-piguet.html>; David Anthoff et al., 'Global and Regional Exposure to Large Rises in Sea-level: A Sensitivity Analysis' (Tyndall Centre for Climate Change Research, 2006) <http://www.tyndall.ac.uk/sites/default/files/wp96_o.pdf>.

22 McAdam et al. (n 12$) 23$.

23 Byravan, Rajan (n 13) 240.

24 The only regions in which sea-level rise is not included as a key risk are Central and South America. See IPCC, 'Summary for Policymakers' in Climate Change 2014: Impacts, Adaptation, and Vulnerability, Part A: Global and Sectoral Aspects, Contribution of Working Group iI to the Fifth Assessment Report of the Intergovernmental Panel on Climate Change (CUP 2014) 21-25. 
a sea-level change. ${ }^{25}$ While more than a third of the existing States in the international community are likely to be directly affected by sea-level rise ${ }^{26}$ with poorer States with a limited response capacity being disproportionately affected - another larger number of States will also likely be indirectly affected, for example, by the displacement of the population of States whose territories submerged partly or disappeared altogether.

Because sea-level rise has become a global phenomenon, international cooperation and assistance are more vital than ever to protect those affected by it. As the work of the ILC has aptly shown, both in the context of the topic 'Protection of Persons in the event of Disasters' and also of the new topic 'Sealevel rise in relation to international law', the underlying principles in the protection of persons in the event of disasters, including sea-level rise, are those of solidarity and cooperation among nations and among individual human beings. ${ }^{27}$

\section{The Duty to Cooperate under International Law}

3.1

The Duty to Cooperate under General International Law

While the term 'cooperation' has never been defined by an international treaty or a resolution of an international organisation, its meaning can be derived from various documents as 'the voluntary coordinated action of two or more States which takes place under a legal regime and serves a specific objective'.28

Cooperation has progressively gained prominence over the course of the twentieth century and particularly after World War II, constituting the linchpin for peaceful relations between States by prescribing limits on absolute State sovereignty. ${ }^{29}$ Today, it finds its expression in a myriad of areas of international legal relations and is recognised as a cornerstone principle

25 IPCC, 'Summary for Policymakers' in Climate Change 2014: Synthesis Report. Contribution of Working Groups I, II and III to the Fifth Assessment Report of the Intergovernmental Panel on Climate Change (2014) 13.

26 ILC (n 1$)$ para. 1.

27 ILC, 'Second report on the protection of persons in the event of disasters by Mr Eduardo Valencia-Ospina, Special Rapporteur' (7 May 2009), UN Doc A/CN.4/615 para. 5o; ILC (n 1 ) para. 17 (ii).

28 Rüdiger Wolfrum, 'Cooperation, International Law of' (2010) Max Planck Encyclopaedia of Public International Law, para. 2.

29 Patricia Wouters, "Dynamic cooperation' in international law and the shadow of State sovereignty in the context of transboundary waters' (2013) 3 Environmental Liability, $88-89$. 
of international law..$^{30}$ Contrary to other principles aimed at restraining certain behaviour, the principle of cooperation is positive in nature and serves as a tool for the realisation of objectives which cannot be accomplished unilaterally by States. ${ }^{31}$

The essence of the principle of cooperation can be found in the purposes of the United Nations (UN) Charter. As set out in Articles 1(1) and 1(3), one of the Charter's central objectives is cooperation in the maintenance of international peace and security as well as in the solving of international problems of an economic, social, cultural or humanitarian character. ${ }^{32}$ Other articles of the UN Charter, in particular Articles 55 and 56 , elaborate on Article 5 by establishing specific cooperation duties, including States' obligations to act jointly and in cooperation with the United Nations to achieve social and economic development and higher standard of living. ${ }^{33}$

States have reiterated their commitment to international cooperation on many occasions. The 1970 Declaration on Principles of International Law concerning Friendly Relations and Cooperation among States lists cooperation as one of the seven fundamental principles of international law, thereby confirming its status as a cornerstone principle in international legal relations. Since then, cooperation has been repeatedly framed as a global imperative. ${ }^{34}$ In 2005, for instance, Heads of State and Government adopted United Nations General Assembly (UNGA) Resolution 6o/1 in which they reaffirmed their belief that no State can stand alone in the interdependent world in which we live and subsequently confirmed their commitment to enhancing international cooperation in the areas of development, security, and human rights. ${ }^{35}$ In 2015, international cooperation found also expression in the fulfilment of the Sustainable Development Goals, with the adoption of UNGA Resolution 70/1, in which States stressed the need for cooperation on the path towards sustainable development. ${ }^{36}$ States once more acknowledged the need to strengthen

30 See Laurence Boisson de Chazournes and Jason Rudall, 'Chapter 6: Co-operation' in Jorge E. Viñuales (ed), The UN Friendly Relations Declaration at 50: An Assessment of the Fundamental Principles of International Law (CUP 2020), 105; Jost Delbrück, 'The international obligation to cooperate - an empty shell or a hard law principle of international law? A critical look at a much-debated paradigm of modern international law', in Coexistence, Cooperation and Solidarity (Brill 2011) 13 .

31 Boisson de Chazournes and Rudall (n 29) 106.

32 United Nations Charter, 26 June 1945, arts. 1(1) and 1(3).

33 Ibid., arts. 55 and 56.

34 UNGA, 'In larger freedom; towards development, security and human rights for all Report of the Secretary General' (21 March 2005) UN Doc A/59/2005, para. 18.

35 UNGA Res 6o/1 (16 September 2005) UN Doc A/REs/6o/1.

36 UNGA Res 70/1 (25 September 2015) UN Doc A/REs/70/1. 
international cooperation when commemorating the $75^{\text {th }}$ anniversary of the $\mathrm{UN}$ in $2020 .{ }^{37}$ Other instruments of a universal nature have proceeded to apply cooperation to specific contexts, including, but not limited to, international economic relations, ${ }^{38}$ the settlement of disputes, ${ }^{39}$ and State responsibility. ${ }^{40,41}$

The institutionalisation of cooperation in the legal framework of the UN reflects a consensus on the centrality of cooperation in international legal relations and confirms the existence of a minimum and general duty for States to engage with each other. ${ }^{42}$ However, the content and scope of this duty remain unclear in practice. Because the meaning of cooperation can only be derived from the specific goal it pursues, ${ }^{43}$ international legal scholarship has turned to consider the expression of cooperation in various specialised areas, in an effort to 'add shades of colour' to the general duty to cooperate. ${ }^{44}$

With the same goal in sight, this article now turns to two such areas in an effort to draw the contours of the duty to cooperate, namely IDL (Section 3.2) and IHRL (Section 3.3).

\subsection{The Duty to Cooperate under International Disaster Law}

Sea-level rise, its effects, and associated extreme events are clearly capable of reaching the level of a "disaster". The commentary to the ILC's Draft Articles, for example, mentions sea-level rise as a slow-onset event potentially covered by the definition of disasters. ${ }^{45}$ Similarly, although not mentioned explicitly by the International Federation of the Red Cross and Red Crescent Societies (IFRC) in its 2007 Guidelines for the Domestic Facilitation and Regulation of International Disaster Relief and Initial Recovery Assistance (IDRL Guidelines), the effects of sea-level rise fall within that document's definition of a disaster - 'a serious disruption of the functioning of society, which poses

37 UNGA Res 75/1 (21 September 2020) UN Doc A/REs/75/1.

38 UNGa Res 3201 (1 May 1974) UN Doc A/RES/S-6/3201.

39 UNGA Res 37/10 (15 November 1982) UN Doc A/Res/37/10.

40 ILC, 'Yearbook of the International Law Commission', 2001, vol. II (Part Two), 113-114, art. 41.

41 Boisson de Chazournes and Rudall (n 29) 112-113.

42 Ibid., 113; Rüdiger Wolfrum (n 27) paras. 1-40.

43 Wolfrum (n 27) para. 2.

44 Boisson de Chazournes and Rudall (n 29); Delbrück (n 29); Christina Leb, 'One step at a time: international law and the duty to cooperate in the management of shared water resources' (2014) 40 Waters International 21.

45 ILC (n 2), commentary (4) to art. 1. In the same sense, Giulio Bartolini, 'A Taxonomy of Disasters in International Law' in Flavia Zorzi Giustiniani et al (eds) Routledge Handbook of Human Rights and Disasters (Routledge 2018), 18-19. 
a significant, widespread threat to human life, health, property or the environment (...).46 Thus, an assessment of the duty to cooperate to protect persons from the effects of sea-level rise must also consider the field of IDL.

This, however, is no easy task, given that IDL is a piecemeal body of law. ${ }^{47}$ It lacks a unitary, universal binding framework and is instead composed of numerous bilateral and regional treaties, sometimes ratified by only a handful of countries. The few universal agreements that exist, besides not having been universally ratified, deal with specific aspects of disaster response or with particular types of disasters. ${ }^{48}$ Moreover, in light of the absence of a coherent framework, several actors have strived to formulate and harmonise standards through different instruments, such as the Measures to Expedite International Relief, ${ }^{49}$ the Guiding Principles on Humanitarian Assistance, ${ }^{50}$ the Guidelines on the Use of Foreign Military and Civil Defence Assets in Disaster Relief, ${ }^{51}$ the Humanitarian Charter and Minimum Standards in Humanitarian Response, ${ }^{52}$ the Hyogo Framework for Action, ${ }^{53}$ and its successor, the Sendai Framework for Disaster Risk Reduction. ${ }^{54}$ As a result of the current patchwork-like nature of this body of law, it is therefore difficult to identify, with a high degree of precision, the content of a general and universally applicable duty to cooperate in IDL.

This difficulty notwithstanding, the field of IDL, however fragmented, is in itself a manifestation of solidarity and cooperative conduct. It is precisely because States act cooperatively to achieve common goals - for example, to reduce the risk of disasters or facilitate the timely and coordinated provision of relief - that bilateral, regional, and universal treaties are formulated

$46 \quad$ IFRC, 'Guidelines for the Domestic Facilitation and Regulation of International Disaster Relief and Initial Recovery Assistance' (2007) 30IC/07/R4 annex, guideline 2.1.

47 Andrea de Guttry, 'Surveying the Law' in Andrea de Guttry, Marco Gestri, and Gabriella Venturini (eds), International Disaster Response Law, 4-6.

48 E.g., Tampere Convention on the Provision of Telecommunication Resources for Disaster Mitigation and Relief Operations, 18 June 1998; Convention on Assistance in the Case of a Nuclear Accident or Radiological Emergency, 26 September 1986; Framework Convention on Civil Defence Assistance, 22 May 2000.

49 IFRC, 'Measures to Expedite International Relief' (1 January 1977).

5O UNGA Res 46/182 (19 December 1991) UN Doc A/RES/46/182.

$5^{1}$ оснA, 'Oslo Guidelines: Guidelines on The Use of Foreign Military and Civil Defence Assets in Disaster Relief' (Revision 1.1) (28 November 2007).

$5^{2}$ Sphere Association, The Sphere Handbook: Humanitarian Charter and Minimum Standards in Humanitarian Response $\left(2018^{4}\right)$.

53 World Conference on Disaster Reduction, Hyogo Framework for Action 2005-2015: Building the Resilience of Nations and Communities to Disasters (22 January 2005).

54 World Conference on Disaster Reduction, Sendai Framework for Disaster Risk Reduction 2015-2030 (18 March 2015). 
and ratified. The provisions agreed upon in that field thus represent further specifications of the meaning of cooperation, as the general duty to cooperate under international law and the cooperative character of IDL get translated into concrete obligations in the context of treaty regimes, whether bilateral or multilateral, and often under an institutional umbrella. ${ }^{55} \mathrm{~A}$ brief survey of IDL instruments can therefore reveal an array of forms of cooperative conduct which States frequently commit to undertake. ${ }^{56}$

One of these forms is the commitment to exchange information and communicate with other States and relevant actors, ${ }^{57}$ whereas another one relates to the provision of scientific and technical assistance. ${ }^{58}$ Yet another type of cooperative conduct is the presence of arrangements to facilitate the provision of the necessary relief personnel, supplies, and equipment, as well as the actual provision of assistance once a disaster has occurred. ${ }^{59}$ Moreover, increasing attention has been given to forms of cooperation with a view to strengthening preparedness and the capacity to prevent disasters and mitigate their effects, ${ }^{60}$ a trend which is confirmed by the Hyogo and Sendai Frameworks.

On the basis of a detailed study of these forms of cooperative conduct, ${ }^{61}$ and also considering especially general international law, IHRL, and the field of disaster relief assistance, ${ }^{62}$ the ILC has included in the Draft Articles a general formulation of the duty to cooperate to protect persons from disasters. ${ }^{63}$

55 For an analysis of these obligations, see ILC, 'Fifth report on the protection of persons in the event of disasters, by Mr. Eduardo Valencia-Ospina, Special Rapporteur' (9 April 2012), UN Doc A/CN.4/652, paras. 79-116.

$5^{6} \quad$ For a more extensive survey, see ILC, 'Memorandum by the Secretariat' (11 December 2007), UN Doc A/CN.4/59o.

57 See, e.g., the Tampere Convention (n 47) and the Framework Convention (n 47), art. $4(\mathrm{a})(1)$.

$5^{8}$ One of the most detailed examples in that regard is the ASEAN Agreement on Disaster Management and Emergency Response, 26 July 2005, arts. 18 and 19.

59 For a useful list of these forms of 'cooperation in response to disaster' see ILC (n 2), paras. 48-49.

6o See, e.g., ASEAN Agreement (n 57), art. 19, stating that scientific and technical cooperation must relate to the 'causes and consequences of disasters and the means, methods, techniques and equipment for disaster risk reduction'.

61 ILC (n 54), paras. 51-116. See also ILC ( $\mathrm{n} 55$ ), especially paras. 51-65.

$62 \quad \operatorname{ILC}(\mathrm{n} 2)$, commentaries (1) to (3) to art. 7 and commentaries (3) and (4) to art. 11.

63 For scholarship about the work of the ILC in relation to cooperation regarding disasters, see: Giustiniani (n 44); Eduardo Valencia-Ospina, "The Work of the International Law Commission on the "Protection of Persons in the Event of Disasters"' (2019) 1 Yearbook of International Disaster Law, 13-15; René Urueña and Maria Angelica Prada-Uribe, 'Disasters, Inter-State Legal Obligations, and the Risk Society: The Contribution of the ILC's Draft Articles' (2019) 1 Yearbook of International Disaster Law; Giulio Bartolini, 'A Universal Treaty for Disasters? Remarks on the International Law Commission's Draft 
According to this formulation, all States, whether affected or not by disasters, have the duty to cooperate. ${ }^{64}$

This duty is made effective through a distribution of responsibilities between affected and non-affected States. Consistent with its 'primary role', derived from the principle of sovereignty, ${ }^{65}$ the affected State bears the 'duty to ensure the protection of persons and provision of disaster relief assistance in its territory' and is responsible for directing, controlling, coordinating, and supervising the provision of relief assistance. ${ }^{66} \mathrm{By}$ virtue of the duty to cooperate and other obligations under international law, the corollary of this primary role is that, when the national response capacity of an affected State is overwhelmed, this State has 'the duty to seek assistance from, as appropriate, other States, the United Nations, and other potential assisting actors'.67 When such assistance is sought, the addressees of the request 'shall expeditiously give due consideration' to it. ${ }^{68}$ On the other hand, even if no requests are made by the affected States, non-affected States and other potentially relevant actors 'may offer assistance' to the former. ${ }^{69}$

Articles on the Protection of Persons in the Event of Disasters' (2017) 1103 International Review of the Red Cross; Thérèse O'Donnell and Craig Allan, 'A Duty of Solidarity? The International Law Commission's Draft Articles and the Right to Offer Assistance in Disasters' in Susan C. Breau and Katja L.H. Samuel (eds) Research Handbook on Disasters and International Law (Edward Elgar 2016); Craig Allan and Thérèse O'Donnell, 'An Offer You Cannot Refuse?: Natural Disasters, the Politics of Aid Refusal and Potential Legal Implications' (2013) 5 Amsterdam Law Forum; Flavia Zorzi Giustiniani, 'The Works of the International Law Commission on "Protection of Persons in the Event of Disasters'. A Critical Appraisal' in Andrea de Guttry et al (eds) International Disaster Response Law (T.M.C. Asser Press 2012); J Benton Heath 'Disasters, Relief, and Neglect: The Duty to Accept Humanitarian Assistance and the Work of the International Law Commission' (2011) 43 New York University Journal of International Law and Politics; Dug Cubie, 'An Enchanted Tool? Humanitarian Assistance and the ILC Draft Articles on the Protection of Persons in the Event of Disasters' (2009-2010) 4-5 Irish Yearbook of International Law.

$64 \quad$ ILC (n 2) art. 7 .

65 Ibid., fifth preambular paragraph.

66 Ibid., art. 10.

67 Ibid., art. 11.

68 Ibid., art. 12(2).

69 Ibid., art. 12(1). For an account of why the language of a 'right to offer assistance' was abandoned at the ILC, see ILC, 'Eighth report on the protection of persons in the event of disasters by Eduardo Valencia-Ospina, Special Rapporteur' (17 March 2016) UN Doc A/CN.4/697, paras. 301-316. 


\subsection{The Duty to Cooperate under International Human Rights Law}

IHRL is also an area of international law that has significantly contributed to clarifying and developing the content and scope of the general obligation of international cooperation provided for in the UN legal framework.

Cooperation in IHRL derives from an understanding of international solidarity as the basis of all human rights. ${ }^{70}$ The underlying premise of human rights-based international solidarity is that, while the prime responsibility for attaining human rights is incumbent on each State, this cannot become effective without strengthening international solidarity between States as well as between States and other actors such as international organisations and civil society. ${ }^{71}$ Solidarity is here understood as 'a communion of responsibilities and interest between individuals, groups and States, connected by the ideal of fraternity and the notion of cooperation' ${ }^{72}$ According to this definition, the relationship between solidarity and cooperation is an integral one, because one can only cooperate in an act of solidarity. ${ }^{73}$ International cooperation is thus a core vehicle through which international solidarity is achieved. ${ }^{74}$

The duty to cooperate is, accordingly, firmly established within instruments of IHRL. The Universal Declaration of Human Rights states that everyone is entitled to the 'realization, through national effort and international cooperation (...) of the economic, social and cultural rights indispensable for [their] dignity and the free development of [their] personality', as well as to 'an international order in which the rights and freedoms set forth in th[e] Declaration can be realized. ${ }^{75}$ The International Covenant on Economic, Social and Cultural Rights (ICESCR), in turn, binds all State parties to take steps 'individually and through international assistance and cooperation, especially economic and technical', towards the full realisation of the rights recognised in the Covenant. ${ }^{76}$ The ICESCR further emphasises the obligation to coop-

70 UNGA, 'Human rights and international solidarity' (22 June 2009) UN Doc A/HRC/12/27, para. 40.

$71 \quad$ ECOSOC, 'Human rights and international solidarity - Working paper submitted by Rui Baltazar Dos Santos Alves (15 June 2004) UN Doc E/CN.4/Sub.2/2004/43, para. 35.

72 UNGA, 'Human rights and international solidarity' (15 August 2008) UN Doc A/H RC/9/10, para. 6 .

73 UNGA, 'Human rights and international solidarity' (1 February 2006) UN Doc E/CN.4/ 2006.96, para. 13 .

$74 \quad$ UNGA (n 71), para. 28.

75 Universal Declaration on Human Rights, 10 December 1948, arts. 22 and 28.

76 International Covenant on Economic, Social and Cultural Rights, 16 December 1966, art. 2(1). 
erate in the scientific and cultural fields as well as to ensure the right to be free from hunger. ${ }^{77}$ Additionally, it provides a non-exhaustive list of ways in which international assistance and cooperation may be effected, thereby indicating the minimum positive action expected under its ambit. ${ }^{78}$

The negotiating history of the ICESCR shows that, while all countries stressed the importance of strengthening international cooperation, they disagreed on the nature of this obligation. On the one hand, developed countries supported the existence of a moral responsibility to cooperate internationally. On the other hand, developing countries stated that the ICESCR provided for a legally binding obligation to cooperate for the realization of socio-economic rights. ${ }^{79}$ Despite this controversy, many international instruments have suggested that stronger legal obligations do arise from international cooperation in certain contexts, ${ }^{80}$ substantiating the conclusion that the duty to cooperate is more than a moral responsibility.

In addition, the Committee on Economic, Social and Cultural Rights ("CESCR") has reaffirmed States' obligation to cooperate in the realisation of human rights. In the specific context of natural disasters, the CESCR has, for instance, affirmed that States and international organisations have a joint and individual responsibility to cooperate in providing disaster relief and humanitarian assistance in times of emergency. ${ }^{81}$ The CESCR has further added that each State should contribute to this task to the maximum of its capacity. ${ }^{82}$

The CESCR has also worked to define the nature of the responsibilities arising out of the duty to cooperate. According to the Committee, the full realisation of the rights contained in the Covenant would remain an unfulfilled aspiration in many countries 'in the absence of an active programme of international assistance and cooperation on the part of all those States that are in a position to undertake one. ${ }^{83}$ Accordingly, international cooperation

\footnotetext{
$77 \quad$ Ibid., arts. $11(1)$ and $15(4)$.

78 Ibid., art. 23 .

79 Ecosoc, 'Report of the Open-ended Working Group to Consider Options Regarding the Elaboration of an Optional Protocol to the International Covenant on Economic, Social and Cultural Rights on its Third Session' (14 March 2006) UN Doc E/CN.4/2006/47.

$80 \quad$ Boisson de Chazournes and Rudall (n 29) 130.

81 CESCR, 'General Comment No. 14 (2000) on article 12 of the International Covenant on Economic, Social and Cultural Rights, on the right to the highest attainable standard of health' (11 August 2000) UN Doc. E/C.12/2000/4, para. 40.

$82 \quad$ Ibid.

83 CESCR, 'General Comment No. 3 (1990) on article 12(1) of the International Covenant on Economic, Social and Cultural Rights, on the nature of States Parties' obligations' (14 December 199o) UN Doc E/1991/23, para. 14.
} 
for the realisation of economic, social and cultural rights is 'an obligation of all States' - although those States who are in a position to assist others bear a heavier commitment. ${ }^{84}$ For example, States should facilitate the realisation of the right to water in other countries 'depending on the availability of resources. ${ }^{85}$ Ultimately, extraterritorial obligations relating to international cooperation are complementary to the primary responsibility of States to meet their national human rights obligations. ${ }^{86}$

More recently, in 2017, the Independent Expert on human rights and international solidarity has gone as far as to define States' extraterritorial duty to fulfil ICESCR rights as one for 'States in a position to do so to provide assistance, acting separately or jointly, to contribute to the fulfilment of human rights in other States in a manner consistent with the fundamental principles of international law and international human rights law'.87

IHRL is the most developed area of international law dealing with the protection of the rights and interests of human beings. Moreover, its specific relevance for people affected by disasters has been progressively recognised by UN treaty bodies. The CESCR, for instance, has stressed that States' obligation to fulfil the right to adequate food 'also applies for persons who are victims of natural or other disasters. ${ }^{88}$ Likewise, the Committee on the Rights of the Child has mentioned disaster-related issues in more than twenty of its concluding observations. ${ }^{89}$ The duty to cooperate for the realisation of human rights, therefore, also applies to the protection of persons from disasters, in general and from the effects of sea-level rise, specifically.

\section{$84 \quad$ Ibid.}

85 CESCR, 'General Comment No. 15 (2003) on articles 11 and 12 of International Covenant on Economic, Social and Cultural Rights, on the right to water' (20 January 2003) UN Doc E/C.12/2002/11, para. 34 .

86 нRC, 'Report of the independent expert on human rights and international solidarity, Rudi Muhammad Rizki' (5July 2010) UN Doc A/HRC/15/32, para. 43 .

$87 \quad$ HRC, 'Report of the independent expert on human rights and international solidarity, Virginia Dandan, Annex: Draft Declaration on the right to international solidarity (25 April 2017) UN Doc A/HRC/35/35, art. 2. It remains to be seen whether this Draft Declaration will gain enough traction among States.

88 CESCR, 'General Comment No. 12 (1999) on article 11 of the International Covenant on Economic, Social and Cultural Rights, on the right to adequate food' (12 May 1999) UN Doc E/C.12/1999/5 (1999), para. 15 .

89 Walter Kälin, 'The Human Rights Dimension of Natural or Human-Made Disasters' (2012) 55 German Yearbook on International Law, 127. 

Protection of Persons Affected by Sea-Level Rise

On the basis of the above conclusions, the present article now proceeds to draw the contours of the duty of non-affected States to cooperate in the specific context of the protection of persons affected by sea-level rise. As aptly recognised by the ILC Special Rapporteur on the protection of persons in the event of disasters, the legal and practical effectiveness of a general duty to cooperate to protect persons in the event of disasters must strike a fine balance between different considerations, amongst which the sovereignty of the affected State, the clear delimitation of the burden on assisting States and the careful consideration of the forms that cooperation may take..$^{90}$

To guide the present discussion, two scenarios may be distinguished. First, the situation where, despite not being capable of adequately protecting persons from the effects of sea-level rise, an affected State refrains from seeking external assistance. In this case, the discussion bears on whether non-affected States have an obligation either to provide or to offer assistance, and whether this would constitute a violation of the affected State's sovereignty. The second scenario is that when an affected State, realising that the effects of sea-level rise exceed its national capacity, addresses requests of assistance to non-affected States. In this case, the question is whether the addressees of these requests have an obligation to provide assistance. In both cases, it is assumed that the affected State lacks the capacity of adequately protecting its population from the effects of sea-level rise, given that where the affected State has the necessary capacity to do so, other States, at least in that limited regard, do not have an obligation to cooperate with a view to protecting persons.

\subsection{The Absence of a General, Unqualified Duty to "Provide" Assistance}

In 2011, the ILC addressed to States the question of whether the duty to cooperate in disaster relief matters includes a duty on non-affected States to provide assistance upon request by an affected State. ${ }^{91}$ The overwhelming majority of States that responded were categorical in affirming that no such obligation exists. ${ }^{92}$ Taking these views into consideration and analysing different sources of international law, the Special Rapporteur concluded that the duty to cooperate does not encompass a duty for States to provide assistance upon request. ${ }^{93}$

90 $\quad$ ILC (n 54$)$, paras. 93-116.

91 ILC, 'Yearbook of the International Law Commission', 2011, vol. II (Part Two), 20, para. 44.

92 For a summary of these manifestations, see ILC (n 54), paras. 51-54 and 67-68.

93 Ibid., para. 68. 
Similarly, the commentary to the Draft Articles states that offers of assistance, 'whether made unilaterally or in response to a request, are essentially voluntary and should not be construed as recognition of the existence of a legal duty to assist.' 94

As in the broader context of disasters, the duty of non-affected States to cooperate to protect persons affected by sea-level rise does not entail a general obligation to provide assistance to affected States. To understand why no such obligation exists, it is useful to briefly address, in turn, the two scenarios mentioned above. First, in the scenario where a State, despite being overwhelmed by the effects of sea-level rise, does not address requests or calls to foreign actors, the provision of assistance without the consent of the affected State would constitute a forceful act in breach of the affected State's sovereignty and would in fact negate the logic of cooperation. On the other hand, where an affected State requests outside assistance (the second scenario), the Draft Articles make it clear that addressees of these requests have only the obligation 'to expeditiously give due consideration to the request and inform the affected State of its reply'. ${ }^{95}$ Non-affected States, in other words, do not have an obligation to effectively provide assistance upon request.

Given that the Draft Articles operate at a high level of generality, dealing with all types of disasters and making no distinction as to the characteristics of the States which receive requests for assistance, this conclusion is irreproachable. As a general category, non-affected States should not bear the excessive burden of an unconditional obligation to provide assistance whenever a request is addressed to them. Indeed, this would affect disproportionately those States 'which may not be in the position to adequately and effectively discharge their primary obligation towards their own populations. ${ }^{96}$

Naturally, this is without prejudice to the possible existence of a special obligation to provide assistance upon request under specific treaties or institutional contexts. Such an obligation is present in many bilateral arrangements ${ }^{97}$ and appears in some regional treaties. ${ }^{98}$ But, for the reasons explained above,

\footnotetext{
94 ILC (n 2), commentary (2) to art. 12.

95 Ibid., art. 12(2).

$96 \quad$ ILC (n 54), para. 6o.

97 Examples in ILC ( $\mathrm{n} 55)$, fn 220.

98 E.g.: Agreement establishing the Caribbean Disaster Emergency Response Agency of the Caribbean Community, 26 February 1991, art. 13; Treaty on the Functioning of the European Union, 25 March 1957, art. 222(2); and Agreement among the Governments of the Participating States of the Black Sea Economic Cooperation on Collaboration in Emergency Assistance and Emergency Response to Natural and Man-made Disasters, 15 April 1998, arts. 3(2), 3(3) and 4(2).
} 
and as a matter of both law and practicality, there exists no general duty to provide assistance to affected States going beyond those obligations to which States have voluntarily and explicitly agreed.

Despite the soundness of this conclusion, a more complex legal issue might emerge as the analysis descends to a level of increasing concreteness and takes into account the characteristics of specific non-affected States in each particular circumstance. In that regard, it could be argued that a more stringent obligation to consider the request positively and to offer assistance might exist for those non-affected States for whom such burden would not be excessive. This analysis can only be made in concrete cases, but a set of criteria for making such assessment will be tentatively presented in Section 4.3 below.

\subsection{Towards a General Duty to "Offer" Assistance}

Coming back to the scenario where an affected State, despite being overwhelmed by the effects of sea-level rise, does not formulate a request for assistance in protecting its population, it is clear that no unqualified duty to provide assistance can exist for non-affected States. This conclusion, albeit legally sound, can conflict with the moral and legal imperatives that demand that people be protected also from actions or inactions of their own State. What must be sought is therefore an alternative which attends to these imperatives and, at the same time, escapes the sovereignty-impinging flaws of an alleged duty to provide assistance.

It could be argued that, as a manifestation of their general obligation to cooperate, arising from general international law and further specified by IH RL and IDL, non-affected States have a duty to offer the necessary assistance to affected States whose national capacity is insufficient to adequately protect people from the effects of sea-level rise, even if no request has been made to that effect. Without encroaching upon the affected State's sovereignty, this duty would be a legally sound manner of operationalizing the obligations of nonaffected States to cooperate as applied to the protection of persons affected by sea-level rise.

Besides some statements in the Sixth Committee of the UNGA in which States suggested the existence of a duty to offer assistance, ${ }^{99}$ many instruments of IDL or related to humanitarian assistance deal either with a right or a duty to offer assistance. This is the case, for example, of the 1992 Guiding Principles on the Right to Humanitarian Assistance, ${ }^{100}$ the 2003 resolution of the Institut de

$99 \quad$ ILC (n 54), para. 68.

100 Council of the International Institute of Humanitarian Law, 'Guiding Principles on the Right to Humanitarian Assistance' (April 1993), principle 5. 
Droit international on humanitarian assistance ('the Bruges resolution'), ${ }^{101}$ and, with a more stringent language, the 1995 Mohonk Criteria for Humanitarian Assistance in Complex Emergencies. ${ }^{102}$ In the latter instrument, the reference is to 'the right and obligation to protect and provide relief', but the caveat that this must be 'in conformity with the principles of international law' can be taken to mean that the sovereignty of the affected State cannot be bypassed.

Some binding instruments similarly recognize - either implicitly or explicitly - that unsolicited offers of assistance are acceptable. The ASEAN Agreement, ${ }^{103}$ the Inter-American Convention to Facilitate Disaster Assistance, ${ }^{104}$ and the Framework Convention on Civil Defence Assistance ${ }^{105}$ are examples in that regard.

Although, either for the lack of formal bindingness of certain documents, for the use of merely suggestive language or for the limited number of States parties to specific treaties, these instruments do not create duties for all States, they nonetheless reveal the underlying logic that offers of assistance are in accordance with the general goals, principles, and cooperative character of IDL and IHRL. As what is at stake is merely an offer, which by definition depends on the acceptance - i.e., the consent - of the affected State to be made concrete, this act is incapable of violating the sovereignty of this State. Indeed, offers of assistance do not constitute an unfriendly act, an interference, or an unlawful intervention by the offering State, and consent is a mandatory requirement for offers to become, in fact, provisions of assistance. ${ }^{106}$ Offering assistance is therefore an act which can ensure compliance with the duty of non-affected States to cooperate in order to protect persons and, at the same time, respect the sovereignty and primary role of the affected State.

Naturally, the duty to offer assistance must be subject to qualifications to alleviate the burden on States which do not have enough resources or capacity to offer and eventually to provide assistance in concrete circumstances. The

101 Institut de Droit International, 'Humanitarian Assistance' (2 September 2003), paras. IV.1 and v.1.

102 Jon M. Ebersole, 'The Mohonk Criteria for Humanitarian Assistance in Complex Emergencies: Task Force on Ethical and Legal Issues in Humanitarian Assistance' (1995) 17 Human Rights Quarterly, 192-208, criterion II.4.

103 ASEAN Agreement ( $\mathrm{n}_{57}$ ), arts. 3.1 and 11.2.

104 Inter-American Convention to Facilitate Disaster Assistance, 6 July 1991, art. II (a).

105 Framework Convention (n 47), art. 3 (a), (b) and (e).

106 Guiding Principles (n 99), principle 5; Institut (n 10o), paras. IV.1 and IV.2; ASEAN Agreement (n 57), arts. 3.1 and 11.2; IDRL Guidelines (n 45), guidelines 10(1) and 10(2); Framework Convention (n 47), art. 3(b); International Law Association, 'Relief Missions in the event of a natural disaster' (1976), para. I.2. 
Bruges resolution of the Institut is the clearest example of such a qualification, as it affirms that States have a duty to offer assistance 'to the maximum extent possible'. Criteria to guide the assessment of which States bear the duty to offer assistance in each concrete case, and to which extent, will be offered in Section 4.3 below. It can be noted at this stage, however, that the language of 'maximum extent possible' is similar to the formulation of the duty to cooperate in IHRL.

Indeed, as detailed above, under IH RL, States must take steps, individually and through international assistance and cooperation, especially economic and technical, to the maximum of their available resources, and by all appropriate means, with a view to achieving progressively the full realisation of economic, social and cultural rights recognized in the ICESCR. Given that sea-level rise can significantly affect those (and other) rights, IHRL provides an additional legal basis for the duty of non-affected States to offer assistance to an affected State in cases where the latter is unable to protect the human rights of persons affected by sea-level rise. In view of the need to strike a balance between (i) the needs of affected States and their populations, (ii) the duty of non-affected States to cooperate, and (iii) the sovereignty of affected States, this general duty to cooperate can only be one to offer assistance to the 'maximum extent possible'.

\subsection{Operationalizing the General Duty to Cooperate in Relation to the Protection of Persons Affected by Sea-Level Rise}

Should a State affected by sea-level rise not be capable of adequately protecting its population by itself, a general duty to cooperate is applicable by virtue of general international law, IHRL and IDL. Accordingly, non-affected States might either have a duty to offer assistance or a duty to 'expeditiously give due consideration' to requests addressed to them. These obligations are borne, in principle, by all States, and the caveat of 'to the maximum extent possible' applies in both scenarios.

On such a general level, however, these conclusions may still be unsatisfactory for their lack of concrete guidance. It is thus appropriate to flesh out criteria, of an illustrative and non-exhaustive nature, for guiding the identification of: (i) which States bear, in concrete circumstances, the duty to cooperate to protect persons affected by sea-level rise, and to which extent (Section 4.3.1); and (ii) which forms of cooperation are applicable to the protection of persons affected by sea-level rise (Section 4.3.2). 

of Persons Affected by Sea-Level Rise

In principle, all States bear the duty to cooperate with affected States to protect persons affected by sea-level rise. A set of criteria, however, both factual and legal, derived from formally binding international law as well as from soft law, might be offered to guide, in each concrete situation, the identification of specific duty bearers and the extent of the obligations borne by them. Naturally, no definitive answers can be provided in the present, relatively abstract exercise. Moreover, no proposed criterion is definitive in and of itself; only the interplay of different factors will provide an answer in specific cases.

A first criterion is the existence of agreements in force between affected and non-affected States. As mentioned above, binding agreements might impose on States specific duties relating to the offer or provision of assistance to other States parties. In certain cases, as seen above, parties might have a clear obligation to provide assistance when requested.

Another relevant criterion is whether an affected State has addressed requests for outside assistance. This has a direct bearing on whether nonaffected States have, in one case, a duty to offer assistance or, in the other, a duty to give timely and due consideration to requests. Logically, only addressees of requests for assistance can be under an obligation to give due consideration to them. Moreover, in light of the primary role of the affected State and of the legal relevance of consent, great weight must be given to the specific terms and conditions of requests, when they are made. They, in any case, do not limit the scope of the assistance that might still be offered by non-affected States. Offers can go beyond what is explicitly requested by affected States, although they are then subject to the latter's consent to be effectively provided. In addition, when affected States call for international assistance without addressing any specific actor, it might be argued that there is a stronger obligation to consider offering assistance than if no call for assistance existed.

One of the most important criteria to operationalize the duty to cooperate relates to the financial and technical capability of a non-affected State, normally in direct relation with its developmental stage. ${ }^{107}$ Arguably, the more financial and technical capabilities a State has, the more stringent is its obligation to offer assistance to affected States or consider requests thereof. International human rights law has been explicit in that regard. ${ }^{108}$ The CESCR,

\footnotetext{
107 In a similar sense, see Valencia-Ospina (n 62) 14.

108 Although they fall outside the scope of the present article, it is useful to note that other fields of international law give legal significance to similar distinctions, most noticeably
} 
for example, has clarified that cooperation is 'particularly incumbent upon those States which are in a position to assist others.' ${ }^{109}$ The same logic has been adopted in relation to the reduction of the risk of disasters. ${ }^{110}$ There is no reason why these considerations under IHRL and IDL should not apply to the case of sea-level rise. The rationale justifying this criterion is evident in the 2003 Bruges resolution of the Institut, according to which offers of assistance are not required from States when 'such assistance would result in seriously jeopardising their own economic, social or political conditions.'111

Another important criterion is the possible existence of States with expertise that is particularly relevant to protect people from the effects of sea-level rise. As will be seen below, sea-level rise, its effects, and associated hazards can be addressed through a combination of measures including, for example, the construction of hard defences, the restoration of ecosystems and the adaptation of existing houses and infrastructures. Therefore, States with relevant expertise in these domains, depending also on what is needed and effective in each specific circumstance, might bear a more stringent duty to offer assistance or give due consideration to requests thereof.

Yet another possible criterion relates to the geographical proximity between affected and non-affected States. This criterion is justified both by considerations of practicality and by the fact that it tracks our moral intuitions. It might be argued that, among States with similar capacities, under the same abstract legal obligations and in similar conditions under the previous criteria, those geographically closer to the affected States bear a more stringent obligation to assist the latter, as they are likely to be capable of providing assistance more quickly and effectively than distant States. Noticeably, the 2003 Bruges resolution of the Institut stipulates that '[s]pecial attention should be paid to disasters affecting neighbouring States.'112

4.3.2 The Timing and Content of the Duty to Cooperate in Relation to the Protection of Persons Affected by Sea-Level Rise

To effectively protect people affected by sea-level rise, the duty of non-affected States to cooperate must be applicable both in prevention and in relief. For present purposes, prevention is understood as a comprehensive term

perhaps international environmental law with its principle of common but differentiated responsibilities.

109 CESCR (n 82).

110 See Sendai Framework (n 53), para. 38 .

111 Institut (n 100), para. v.1.

112 Ibid. 
encompassing those measures taken to avoid, mitigate, or reduce the risk of disasters or of other situations impairing the enjoyment of human rights. Relief, on the other hand, is meant to cover urgent responses immediately before, during, or after a distressing situation. Other possible types of measures, such as those relating to recovery, reconstruction and rehabilitation, can also be understood, for the purposes of this article, as coming within the scope of prevention, as they will be most significant when they are implemented in ways which reduce further risks. ${ }^{113}$

Prevention is the most effective way of addressing the effects of sea-level rise. ${ }^{114}$ These effects can be tackled through measures of protection (such as the construction of hard defences or the restoration of coastal ecosystems), accommodation (for example, by raising house elevation and adapting construction codes), advance (by recuperating land above sea-level), and retreat (by moving people and constructions away from certain coastal areas). ${ }^{115}$ With the exception of retreat, which might also be necessary in the face of an impending or actual hazard, these measures are mostly preventive. Naturally, they might often be adopted after serious effects of sea-level rise have begun to be felt, but their primary purpose is to curtail further risks, rather than to respond to past ones.

This is not to say that relief is irrelevant. In fact, once extreme events associated with sea-level rise have occurred, relief must become the immediate priority until the most acute effects of such events have been addressed. Crucially, however, there is no reason to argue that the duty to cooperate exists in the case of relief but not in the case of prevention. If an affected State has no sufficient capacity to adopt a relevant combination of preventive measures to protect their population from the effects of sea-level rise, non-affected States with a capacity to do so have a duty to cooperate with the affected State to that end through offering relevant assistance or giving due and timely consideration to requests for assistance. Indeed, the International Law Association's Sydney Declaration of Principles on the Protection of Persons Displaced in the

113 For a comprehensive list of terminology, although not entirely coincident with the definitions adopted in this article, see: Report of the Open-Ended Intergovernmental Expert Working Group on Indicators and Terminology Relating to Disaster Risk Reduction, UN Doc. A/71/644 (1 December 2016).

114 Measures to tackle the causes of sea-level rise have been purposefully left out from the analysis. As these measures, under the label of 'mitigation', are better addressed by the climate regime, they fall beyond the scope of the present article - although cooperation is also relevant in that regard.

115 Michael Oppenheimer et al, 'Sea Level Rise and Implications for Low-Lying Islands, Coasts and Communities' in H.-O. Pörtner et al. (eds) IPCC Special Report on the Ocean and Cryosphere in a Changing Climate (2019) $385-387$. 
Context of Sea-Level Rise ("the Sydney Declaration") applies the duty to cooperate both in prevention and in relief. ${ }^{116}$

The concrete manifestations of the general duty to cooperate are not the same for prevention and for relief. Only in the latter case, for example, is the duty to offer or consider the provision of relief personnel, supplies, and equipment relevant. Moreover, the realisation of the duty to cooperate in prevention might be dependent on risk assessments. It might therefore be argued that there is a sliding scale according to which the content and urgency of the duty to cooperate in the case of prevention will depend on the degree of the risks faced by specific States or communities.

This being said, the following paragraphs offer, in a non-exhaustive manner, examples of specific forms of assistance that might flow from the general duty to cooperate as applied to the protection of persons from the effects of sea-level rise. Given that relief assistance has a clearer content, encompassing the necessary personnel, supplies, equipment and other resources to address the specific needs on the ground, the following considerations will be mainly devoted to forms of assistance in the field of prevention. In all cases, the duty to cooperate is an obligation of conduct, not of result.117

As a first example, cooperation can take the form of negotiations. By virtue of the duty to cooperate, as applied to the protection of persons affected by sea-level rise, States have the duty to negotiate in good faith to develop the normative and institutional landscape relating to such protection. This can signify, for example, the negotiation of bilateral, regional, or universal treaties, the creation of new institutions, or the strengthening of currently existing institutions to improve their capacity to address the needs of people affected by sea-level rise.

Another relevant form of cooperation relates to communication and exchange of information. It could be argued that States have a duty to ensure that information on sea levels is regularly shared with all interested States. Similarly, cooperation in that form can be made concrete through the joint management of early warning systems to detect the possible occurrence of hazards associated with sea-level rise in a timely manner.

Cooperation to protect persons affected by sea-level rise may also include scientific and technical assistance, as well as, potentially, transfers of technology and know-how. This may relate to the knowledge and technical resources necessary to construct hard defences such as dikes, seawalls, barriers and

116 ILA, 'Sydney Declaration of Principles on the Protection of Persons Displaced in the Context of Sea-Level Rise' (2018), principle 4.

117 ILC (n 54), paras. 85-92 and ILC (n 2), commentary (10) to art. 9. 
the like, or to restore or conserve coastal ecosystems, to mention only a few examples.

Cooperation can also take the form of financial support for affected States. This might require, for example, that certain non-affected States incentivise private actors under their jurisdiction to offer such support or, as suggested by the commentary to the Sydney Declaration, that these States provide support through funding mechanisms for humanitarian action, development banks, and the Green Climate Fund. ${ }^{118}$

Finally, a last category of forms of cooperation which assume great importance in the case of sea-level rise relates to persons displaced as a consequence or in anticipation of its effects. The Sydney Declaration offers much-needed guidance in this respect. ${ }^{119}$ Depending on the circumstances, non-affected States might have the duty to facilitate the cross-border movement of people or offer possibilities of temporary or permanent residence in their territory. Cooperation might also include the creation of bilateral or regional arrangements to manage migratory and displacement patterns. It is also important to consider that, in certain circumstances, some effects of sea-level rise might make the return of persons to their place of original residence impractical or impossible. For this reason, cooperation should also include the coordination of efforts to find sustainable and durable solutions for displaced persons.

\section{5}

\section{Conclusion}

The need to protect persons affected by sea-level rise is of the utmost importance, and this can only be fully achieved through international cooperation. It is in light of the relevance of international cooperation that the present article has sought to shed light on the content and manifestations of non-affected States' duties to cooperate to protect people affected by sea-level rise.

Drawing upon the content of the duty to cooperate under the branches of international law most immediately relevant in the context of sea-level rise, this article has made a case for the existence of two different duties for non-affected States when affected States are not capable of protecting their population from the effects of sea-level rise. On the one hand, when they have received requests for assistance, non-affected States have a duty to give due

\footnotetext{
118 Davor Vidas et al, 'International Law and Sea Level Rise: Report of the International Law Association Committee on International Law and Sea Level Rise', 2 Brill Research Perspectives in the Law of the Sea, commentary to principle 4.

119 Sydney Declaration (n 115), principles 4(2)(a)(ii), 4(2)(a)(iii), 4(2)(b), 7, and 9.
} 
and timely consideration to these requests. On the other hand, if no requests for assistance have been made, non-affected States might have a duty to offer assistance to affected States.

For purposes of offering guidance on how these duties are to be operationalized in practice, this article has fleshed out criteria for guiding the identification of which States bear these duties in concrete circumstances, and to which extent, and which forms of cooperation are applicable to the protection of persons affected by sea-level rise. While these non-exhaustive criteria are merely tentative at this stage, it is hoped that they can contribute both to the efforts of addressing the threat posed by sea-level rise and to those of clarifying the contours of the duty to cooperate in international law. 